\title{
Evaluation of the toxicity of a methanolic total extract of Mitragyna ciliata a natural anti-malaric
}

\author{
Alain Dit Philippe BIDIE *, Ernest KOFFI, Félix Houphouet YAPI, Alain Aby YÉMIÉ, \\ Joseph Allico DJAMAN and Frédéric GUEDE-GUINA
}

Laboratoire de Pharmacodynamie-Biochimique, UFR Biosciences, Université de Cocody, 22 BP 582 Abidjan 22, Côte d'Ivoire.

*Corresponding author, E-mail: alphbid@yahoo.fr; Tél: (225) 07105826

\begin{abstract}
Mitragyna ciliata (MYTA) is a Rubiaceae used in traditional medicine to treat malaria. Total methanolic extract of MYTA made was used for toxicological studies on laboratory mice and rats. The extract of MYTA was administered intraperitoneally. The doses ranged from 0 to $4000 \mathrm{mg} / \mathrm{kg}$ body weight (bw) (i.e., $0,250,500,1000,2000$ and $4000 \mathrm{mg} / \mathrm{kg} \mathrm{bw}$ ) for acute toxicity, and from 0 to $475 \mathrm{mg} / \mathrm{kg}$ body weight (bw) (i.e., $0,125,250$ and $475 \mathrm{mg} / \mathrm{kg}$ bw) for subacute toxicity studies. Following administration of high doses, the mice had jerky movements and died lying on their belly. The maximal tolerated dose (MTD) obtained was 500 $\mathrm{mg} / \mathrm{kg}$ of bw, whereas $50 \%$ lethal dose $\left(\mathrm{LD}_{50}\right)$ was $1412 \mathrm{mg} / \mathrm{kg}$ of bw. The study of the effects of MYTA on the complete blood count, blood glucose and the serum markers ((urea, uric acid, creatinine, transaminases (GOT, GPT), alkaline phosphatase (ALP), lactate dehydrogenase (LDH), creatinine phosphokinase (CPK)) of noble organs of rats was performed. The results obtained with the serum enzymes (GOT, GPT, ALP, CPK and LDH) showed that no significant increase of activity occurred. This indicated that the heart and liver might not have suffered damages. Besides, significant decreases were observed in the serum activities of GOT, ALP and LDH, suggesting that MYTA could have a potential hepatoprotective effect. Nevertheless, significant increases were observed in the serum concentration of urea, uric acid and creatinine at high doses. This indicates the accumulation of these metabolites in the blood, which could be due to kidney injury, leading to a decrease in renal elimination of waste.
\end{abstract}

(C) 2010 International Formulae Group. All rights reserved.

Keywords: Toxicity, Mitragyna ciliata, anti-malaric.

\section{INTRODUCTION}

Most African people since the dawn of time, use the rich heritage of Africa for treatment. According to Adjanéhoun and AkéAssi (1979), about 5000 plant species have been identified in Côte d'Ivoire. Also, AkéAssi and Sita (1991) identified plants of western Africa used in traditional medicine. Among these plants, Mitragyna ciliata, a
Rubiaceae, has been found to possess many virtues. Indeed MYTA has an immunogenic potential, induced a positive inotropic and negative chronotropic effects on the contractile activity of isolated rat heart, had a hypotensive effect on the carotid artery pressure of rabbit, and caused lung hyperventilation and myorelaxation of rabbit's duodenum (Fofana 2004; Bidié, 2005, 2010). 
MYTA would also be cardiotonic of the digitalic type (Bidié, 2005, 2008, 2010). Furthermore, MYTA is used traditionally to treat malaria (Adjetey, 2007). This antimalaric potential of MYTA has been scientifically proven by Dje et al. (1997). The author has shown that MYTA inhibits in vitro growth of Plasmodium falciparum strain chloroquino-résistante FCM 29. It should also be noted that MYTA is administered orally or intravenously and therefore has access to all body functions. Thus, it seemed interesting to conduct studies of toxicity and biotolerance for a more rational use. The determination of toxicological parameters of the methanolic extract of MYTA therefore seems necessary since it must be administered to living organisms.

Since no toxicological study of total methanolic extract had been conducted to date, we have found it necessary to evaluate acute and subacute toxicities of this extract on laboratory animals. Indeed, the lethal dose 50 $\left(\mathrm{LD}_{50}\right)$, the lethal dose $100\left(\mathrm{LD}_{100}\right)$ and the maximal tolerated dose (MTD) of this phytomedicine were determined in laboratory mice, and some haematological and biochemical parameters in rats.

\section{MATERIALS AND METHODS}

\section{Plant material and preparation of extract} Mitrgyna ciliata (voucher specimen $\mathrm{N}^{\circ}$ 8888, deposited at the herbarium of the "Centre National Floristique (CNF)" of the University of Cocody-Abidjan, Côte d'Ivoire) is a tropical forest plant found in the Republic of Côte d'Ivoire. The methanolic extract from the bark of $M$. ciliata (MYTA) was prepared by stirring $50 \mathrm{~g}$ of finely ground portions in 1,5 L methanol using a magnetic stirrer (IKAMAG RCT) for $48 \mathrm{hrs}$ at room temperature. The methanolic extract was filtered over cotton and Whatman $\mathrm{N}^{\circ} 3$ filter paper three times. The filtrate was evaporated at $40{ }^{\circ} \mathrm{C}$ under reduced pressure with a rotavapor (Buchi 461 Watter Batch). The residue obtained, dissolved in a physiological liquid (Mac-Ewen), was used to prepare MYTA solutions.

\section{Animals}

Swiss mice (males and females) aged 6 to 8 weeks and weighing $20 \mathrm{~g}$ on average, and rats aged 12 weeks and weighing $150 \mathrm{~g}$
(Desfontis, 2004) on average were collected from the Institut Pasteur Adiopodoumé (Côte d'Ivoire).

\section{Methods \\ Acute toxicity}

The mice used for experimentation were of comparable age (6 to 8 weeks) and were placed in cages containing bedding of wood shavings. This litter was renewed every two days. The experiment consisted of 60 mice divided into 12 batches of 5 mice each, with 6 batches of male mice and 6 batches of female mice and substantially equal weight $(20 \pm 0.5 \mathrm{~g})$. Intraperitoneally, different concentrations of MYTA were injected into mice using an insulin syringe of $1 \mathrm{~mL}$. These concentrations $(0,250,500,1000,2000$ and $4000 \mathrm{mg} / \mathrm{kg}$ body weight) were prepared with a physiological solution (Mac- Ewen).

According to Berhens and Karber (1935), the $\mathrm{LD}_{50}$ of a product can be determined using the following formula:

$\mathrm{LD}_{50}=\mathrm{LD}_{100}-\frac{(\mathrm{a} \times \mathrm{b})}{\mathrm{n}}$

with $\mathrm{LD}_{100}=$ dose causing death of all animals in experimentation;

$\mathrm{a}=$ average number of animal death between two successive doses.

$\mathrm{b}=$ difference between two successive doses (mg/kg body weight).

$\mathrm{n}=$ number of animals used per batch or mean animals, with $\mathrm{n}=5$ mice.

\section{Subacute toxicity}

This experiment was conducted in three (03) months to determine the subacute toxicity of the product on animals by injecting the daily dose and repeated concentrations below the $\mathrm{LD}_{50}$ of MYTA. Indeed, 4 batches of 3 rats each, with a control group, were used. For this second part of the study to determine the effect of MYTA on the noble organs (kidney, liver and heart) of animals, varying doses of MYTA were prepared from the MTD (i.e., 0, 125,250 and $475 \mathrm{mg} / \mathrm{kg}$ body weight).

Determination of complete blood count $(C B C)$ and serum markers of kidney, liver and heart

- Determination of the $C B C$ : The method used was that described by Yapi et al. (2009). 
Indeed, whole blood collected in tubes with anticoagulant (EDTA) was used to determine hemoglobin $(\mathrm{Hb})$ concentration and mean blood cells volume (MBCV) using a semiautomatic blood cell counter.

- Urea determination: The enzymatic method used is based on the reaction described by Talke and Schubert (1695). The method has been optimized by Tiffany et al. (1972) who showed that the concentration of urea is proportional to the change in absorbance measured at $340 \mathrm{~nm}$ for a given time. The reaction scheme is as follows:

$$
\begin{aligned}
& \text { Urea }+\mathrm{H}_{2} \mathrm{O} \stackrel{\text { Urease }}{\longrightarrow} 2 \mathrm{NH}_{3}+\mathrm{CO}_{2} \\
& \stackrel{\mathrm{NH}_{3}+\text { Oxoglutarate }+\mathrm{NADH}+\mathrm{H}^{+}}{\stackrel{\text { GLDH }}{\longrightarrow} \text { Glutamate }+\mathrm{NAD}^{+}+\mathrm{H}_{2} \mathrm{O}}
\end{aligned}
$$

- Uric acid determination: According to Fossati et al. (1980) and Tietz (1999), uricase acts on uric acid to produce allantoin, carbon dioxide and hydrogen peroxide. In the presence of peroxidase, hydrogen peroxide reacts with a chromogen (dichlorohydroxybenzene sulfonate and amino-antipyrine) to form a quinonemine which is a red complex. The absorbance measured at $520 \mathrm{~nm}$ is proportional to the amount of uric acid.

- Blood glucose determination: According to the method of Trinder (1969) and Farrance (1987), glucose is oxidized by glucose oxidase (GOD) to form gluconic acid and $\mathrm{H}_{2} \mathrm{O}_{2}$. Then peroxidase (POD) reacts with $\mathrm{H}_{2} \mathrm{O}_{2}$, 4-chlorophenol and the plasma alkaline phosphatase (PAP) to form a red quinonemine. The absorbance of colored complex, proportional to the concentration of glucose in medium, was measured at $500 \mathrm{~nm}$.

- Determination of creatinine: This assay is based on colorimetric reaction (Jaffe reaction without pre-stage processing of the specimen) of creatinine with picric acid in alkaline medium. The kinetics of the reaction is measured at $490 \mathrm{~nm}$. This method has been optimized by Fabiny et al. (1971) and Labbe (1996).

- Determination of transaminases: The serum glutamo-oxaloacetic transaminase (GOT, AST) method was developed by Karmen et al.
(1955) and optimized by Henry et al. (1960) (consistent with the recommendations of the IFCC (1986)). The reaction scheme is as follows:

\section{L-Aspartate + 2-Oxoglutarate \\ AST \\ Oxaloacétate + L-Glutamate}

Oxaloacétate $+\mathrm{NADH}+\mathrm{H}^{+}$

MDH

L-Malate + NAD ${ }^{+}$

The decrease in absorbance, due to conversion of NADH to $\mathrm{NAD}^{+}$and proportional to the AST activity in the specimen, is measured at $340 \mathrm{~nm}$.

The serum glutamo-pyruvic transaminase (GPT, ALT) method was developed by Wrobleski and La Due, and optimized by Henry (1960) and Bergmeyer (1978) (consistent with the recommendations of the IFCC (1986)). The reaction scheme is as follows:

L-Alanine + 2-Oxoglutarate

ALT

Pyruvate + L-Glutamate

Pyruvate $+\mathrm{NADH}+\mathrm{H}^{+}$

LDH

L-Lactate $+\mathrm{NAD}^{+}$

The decrease in absorbance measured at $340 \mathrm{~nm}$ due to conversion of NADH to $\mathrm{NAD}+$ is proportional to ALT activity in the specimen.

- Determination of Alkaline Phosphatase $(A L P)$ : The activity of ALP was determined according to the method of Withold (1996), through the following reaction:

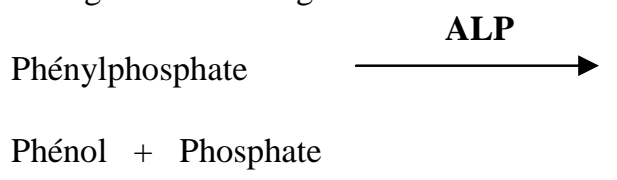

The phenol liberated by hydrolysis of the substrate reacts in the presence of 4amino-antipyrine and potassium ferricyanide to form a red complex whose absorbance is measured at $510 \mathrm{~nm}$ and is directly 
proportional to ALP activity in the specimen. Sodium arsenate was used to stop the enzymatic reaction and prevents instability of the color observed with previous methods.

- Determination of lactate dehydrogenase $(L D H): \quad$ The method of Henry et al. (1974) (consistent with the recommendations of SFBC) was used:

$$
\begin{aligned}
& \text { Pyruvate }+\mathrm{NADH}+\mathrm{H}^{+} \longrightarrow \\
& \text { L-Lactate }+\mathrm{NAD}^{+}
\end{aligned}
$$

The decrease in absorbance (measured at $340 \mathrm{~nm}$ ) due to conversion of NADH to NAD+ was directly proportional to $\mathrm{LDH}$ activity in the specimen.

-Determination of creatinine phosphokinase $(C P K)$ : The activity of CPK was determined according to the method of Fabiny and Ertingsthausen (1971), optimized by Labbé et al. (1996). It is a colorimetric reaction of creatinine with picric acid under alkaline conditions and the kinetics of the reaction measured at $490 \mathrm{~nm}$.

\section{Statistical analysis}

Experiments were run in duplicate, and statistical analyses were performed using the Graph Pad Prism 5.0 software (Microsoft). Analyses of variance (ANOVAs) were conducted and multiple comparisons between means were performed by Tukey and Dunnett procedure. Significance level was defined as $\mathrm{P}$ $<0.05$. Results were given as means \pm standard deviation.

\section{RESULTS \\ Acute toxicity \\ Animal behavior \\ Injection doses of total methanolic extract of MYTA between 250 and 4000 $\mathrm{mg} / \mathrm{kg}$ bw to the animals showed the following events: \\ - Regrouping trends followed by immobilization of the mouse was extended over a period of 3 min to 10 hours depending on the doses administered, \\ - Accelerated respiratory rate (tachypnea) \\ - Tremor \\ - Disruption of feeding behavior (loss of appetite)}

Immobilization and respiratory disorder are signs preceding the death of mice. These animals died lying on their stomach or side. The deaths were recorded in batches 4, 5 and 6 of male and female mice at doses respectively $1000,2000,4000 \mathrm{mg} / \mathrm{kg}$ of bw (Table 1). In control batches of mice, no apparent abnormal signs were observed. The mice kept the same aspect, either on behavioral or nutritional.

After 14 days of observation, all mice died in batch 5 (males and females) over a three-day period. It was observed a gradual recovery of mice from other lots, which was illustrated by a return to normalization of respiratory rate and feeding behavior similar to control groups of mice. Total recovery appeared after 3 days.

\section{Subacute toxicity}

Behavior of rats after 21 days of observation

This second part of the study was conducted on rats divided into 4 lots of 5 rats each with a control lot. The doses used were based on the MTD. Thus the doses ranged from 0 to $475 \mathrm{mg} / \mathrm{kg}$ body weight $(0 ; 125$; $250 ; 475 \mathrm{mg} / \mathrm{kg} \mathrm{bw})$.

Observation of rats 21 days after repeated administration of the product showed no mortality in control lot (lot 1) and in lot 2 of rats. However, in the experimental lots (lot 3 and lot 4) of rats, there were deaths. The dose $250 \mathrm{mg} / \mathrm{kg}$ bw resulted in death of 1 rat during the first 5 days of repeated treatment. The dose $475 \mathrm{mg} / \mathrm{kg}$ bw caused the death of 2 rats on the second day of repeated injection of the product. On the fifth day of treatment, rats from lots 3 and 4 were all weakened. They were motionless with rapid breathing. In addition, there was a change in their nutritional status, which was characterized by a loss of appetite. This change was more pronounced in the lot 4 . During the following 14 days, rat that survived, resumed their usual feeding habits as in controls.

\section{Behavior of rats after 3 months of observation}

During the 40 days following the first 21 days of observation of animals in control groups and experimental batches (batch 2 and batch 3), no conduct disorder or change in their general appearance and nutritional status 
was observed. No mortality was recorded. 30 days (1 month) of observation after these 2 months, no death of any animal throughout the experimental period was recorded. Only some signs of weakness were observed.

\section{Effect on blood cells counts}

This study revealed a variation of white blood cells (WBC), red blood cells (RBC), hemoglobin ( $\mathrm{Hb})$ and platelets after treatment of animals with MYTA (Table 3). Indeed, the $\mathrm{WBC}$ went from $10.47 \pm 0.51$ to $11.78 \pm 0.67, \mathrm{RBC}$ from $8.33 \pm 0.18$ to $9.45 \pm$ $0.43, \mathrm{Hb}$ from $12.52 \pm 0.77$ to $15.21 \pm 0.44$ and platelets from $1077 \pm 25.51$ to $1265 \pm$ 25.41. For other elements of the CBC except the hematocrit (HCT) and Neutrocytes that increase, a general reduction of all other elements (Mean corpuscular volume (MCV), Mean corpuscular hemoglobin $(\mathrm{MCH})$, Mean corpuscular hemoglobin concentration (MCHC), lymphocytes, monocytes Eosinocytes and Basocytes) was observed (Table 3).

\section{Effect on the kidneys}

Biochemical parameters that give an idea of the state of the kidneys or renal activity are: urea, uric acid and creatinine. Generally, increases were observed in the serum concentrations of the three parameters in the experimental groups, compared to the control group. Indeed, for urea, uric acid and creatinine, control values were $0.19 \pm 0.008$;
$25.91 \pm 0.10$ and $7.36 \pm 0.23$, respectively. These values were increased to $0.45 \pm 0.01$; $35.55 \pm 2.93$ and $15.27 \pm 0.44$ respectively; for the dose of $475 \mathrm{mg} / \mathrm{kg}$ body weight of MYTA.

\section{Effect on the heart}

In order to get an idea of the condition of the heart of animals subjected to this experiment, the activities of serum transaminases (GOT, GPT) and other enzyme markers of the integrity of the heart (CPK and LDH) were determined. Indeed, the results revealed a change in experimental values from control values $(\mathrm{GOT}=191.1 \pm 2.93$; GPT $=$ $63.04 \pm 0.4 ; \mathrm{CPK}=101.4 \pm 087$ and $\mathrm{LDH}=$ $242.5 \pm 2.92)$. The experimental values indicate: $(\mathrm{GOT}=173.3 \pm 5.19 ; \mathrm{GPT}=49.11$ $\pm 18.61 ; \mathrm{CPK}=89.38 \pm 9.38$ and $\mathrm{LDH}=$ $195.4 \pm 5.32$ ) after treatment with $475 \mathrm{mg} / \mathrm{kg}$ body weight of MYTA.

\section{Effect on the liver}

In addition to the activity of serum transaminases, CPK and LDH, blood glucose and serum activity of ALP have been identified. Thus, after treatment with MYTA (475 mg/kg of bw), changes in blood glucose from $1.49 \pm 0.008$ (control) to $1.12 \pm 0.27$ and the activity of ALP from $264.6 \pm 1.98$ to $180.4 \pm 11.50$ were observed.

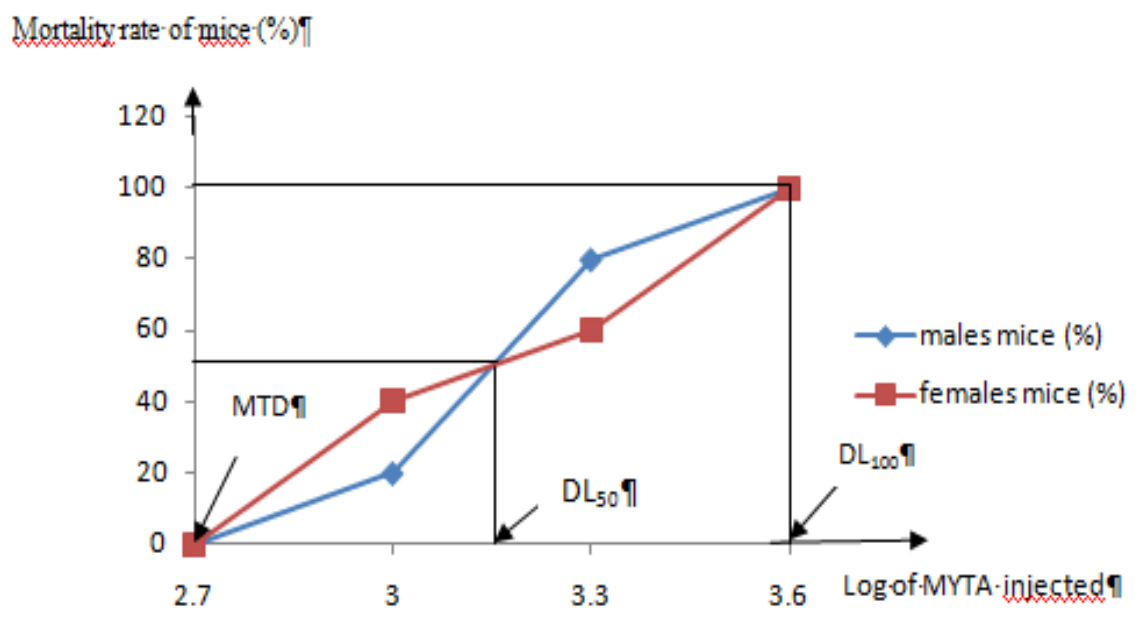

Figure 1: Mortality rate of mice as a function of levels of total methanolic extract of Mitragyna ciliate. MTD: maximal tolerated dose; $\mathrm{LD}_{50}$ : lethal dose 50; $\mathrm{LD}_{100}$ : lethal dose 100. 
Table 1: Mortality of male mice as a function of levels of total methanolic extract of Mitragyna ciliate.

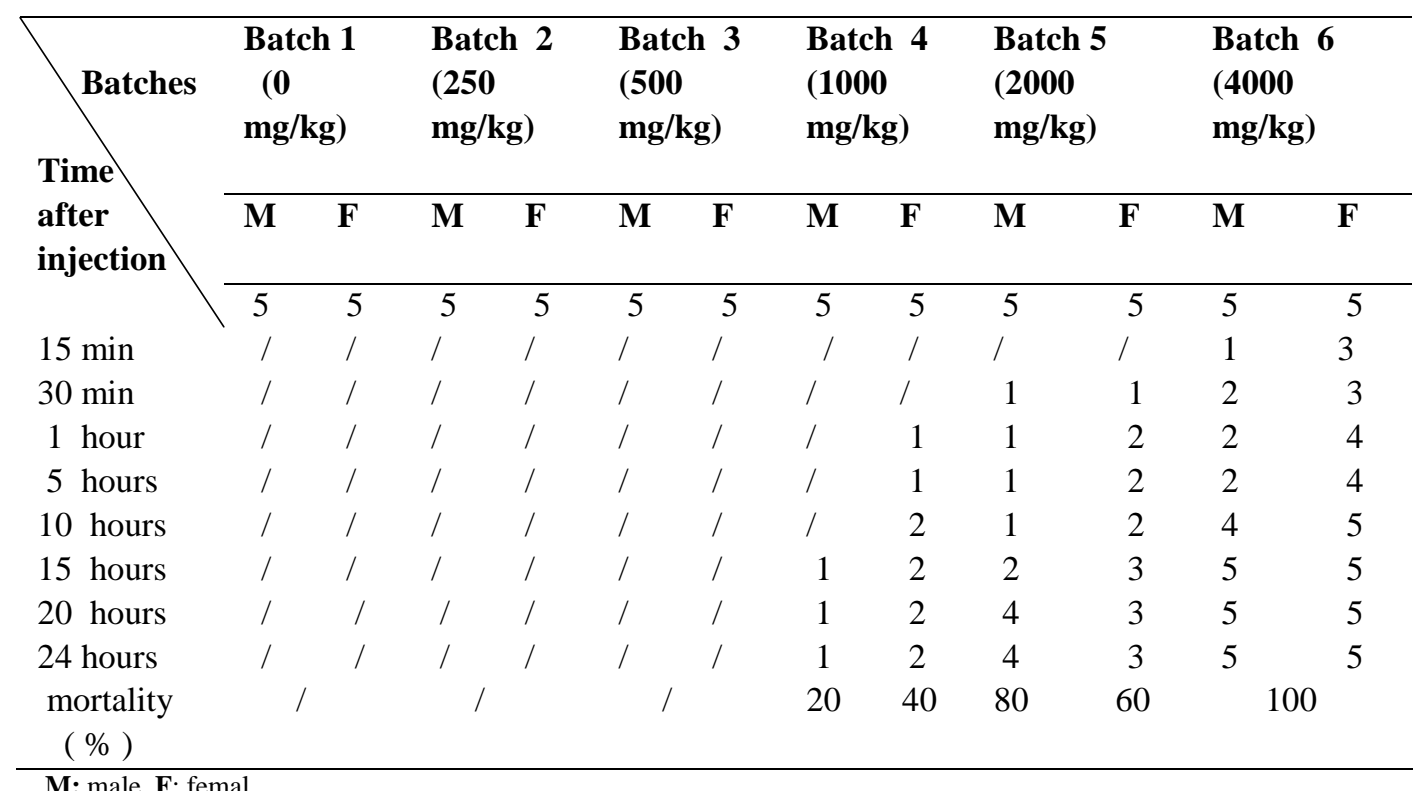

Table 2: Acute toxicity parameters.

\begin{tabular}{llll}
\hline Parameters & MTD & $\mathrm{LD}_{50}$ & $\mathrm{LD}_{100}$ \\
\hline $\begin{array}{l}\text { Extract level } \\
\text { (Total methanolic extract } \quad \text { of }\end{array}$ 500 & 1412 & 4000 \\
Mitragyna ciliata) $(\mathbf{m g} / \mathbf{k g})$ & & & \\
\hline MTD: maximal tolerated dose, $\mathrm{LD}_{50}$ : lethal dose $50, \mathrm{LD}_{100}:$ lethal dose 100 &
\end{tabular}

Table 3: Effect of MYTA on hematological and biochemical parameters of the kidneys, liver and heart.

\begin{tabular}{|c|c|c|c|c|}
\hline Samples & & & & \\
\hline Parameters & $\begin{array}{c}\text { Lot } 1 \\
\text { (Control, } \\
\text { 0 mg/kg) }\end{array}$ & $\begin{array}{c}\text { Lot } 2 \\
(125 \mathrm{mg} / \mathrm{kg})\end{array}$ & $\begin{array}{c}\text { Lot } 3 \\
(250 \mathrm{mg} / \mathrm{kg})\end{array}$ & $\begin{array}{c}\text { Lot } 4 \\
(475 \mathrm{mg} / \mathrm{kg})\end{array}$ \\
\hline $\mathrm{WBC}(\mathrm{WBC} / \mu \mathrm{L})$ & $10.47 \pm 0.51$ & $6.83 \pm 0.20 *$ & $11.78 \pm 0.67$ & $8.58 \pm 0.67$ \\
\hline $\mathrm{RBC}(\mathrm{RBC} / \mu \mathrm{L})$ & $8.33 \pm 0.18$ & $7.03 \pm 0.35$ & $8.62 \pm 0.26$ & $9.45 \pm 0.43$ \\
\hline $\mathrm{Hb}(\mathrm{g} / \mathrm{dL})$ & $12.52 \pm 0.77$ & $12.44 \pm 0.36$ & $12.76 \pm 0.58$ & $15.21 \pm 0.44 *$ \\
\hline HCT (\%) & $41.85 \pm 1.31$ & $40.48 \pm 2.20$ & $39.54 \pm 2.23$ & $42.11 \pm 1.68$ \\
\hline TCMH (pg) & $15.99 \pm 0.13$ & $16.48 \pm 1.18$ & $14.5 \pm 0.46$ & $15.27 \pm 0.40$ \\
\hline $\mathrm{MCHC}(\mathrm{g} / \mathrm{dL})$ & $31.20 \pm 0.27$ & $31.28 \pm 0.46$ & $32.06 \pm 0.42$ & $32.18 \pm 0.21$ \\
\hline Platelets (Platelets $/ \mu \mathrm{L}$ ) & $1077 \pm 25.51$ & $1114 \pm 8.29$ & $1259 \pm 194.3$ & $1265 \pm 25.41$ \\
\hline Lymphocytes (\%) & $63.15 \pm 2.43$ & $61.51 \pm 1.24$ & $57.33 \pm 4.36$ & $56.60 \pm 2.54$ \\
\hline Monocytes (\%) & $6.42 \pm 0.55$ & $5.89 \pm 0.64$ & $4.4 \pm 0.20$ & $4.2 \pm 0.17$ \\
\hline Neutrocytes (\%) & $27.28 \pm 2.94$ & $26.54 \pm 0.75$ & $37.88 \pm 3.68$ & $38.12 \pm 8.32 *$ \\
\hline Eosinocytes (\%) & $2.87 \pm 0.11$ & $2.19 \pm 0.23$ & $1.87 \pm 0.30$ & $1.80 \pm 0.65$ \\
\hline Basocytes (\%) & 00 & 00 & 00 & 00 \\
\hline
\end{tabular}




\begin{tabular}{lcccc} 
Urea $(\mathrm{g} / \mathrm{L})$ & $0.19 \pm 0.008$ & $0.22 \pm 0.008$ & $0.30 \pm 0.005 *$ & $0.45 \pm 0.01 *$ \\
Uric acid $(\mathrm{mg} / \mathrm{L})$ & $25.91 \pm 0.10$ & $26.55 \pm 0.38$ & $28.94 \pm 1.06 *$ & $29.55 \pm 2.93 *$ \\
Creatinine $(\mathrm{mg} / \mathrm{L})$ & $7.36 \pm 0.23$ & $7.94 \pm 0.34$ & $10.10 \pm 0.95 *$ & $15.27 \pm 0.44 *$ \\
Blood glucose $(\mathrm{g} / \mathrm{L})$ & $1.49 \pm 0.008$ & $1.25 \pm 0.04$ & $1.16 \pm 0.25$ & $1.12 \pm 0.27$ \\
GOT $(\mathrm{UI} / \mathrm{L})$ & $191.1 \pm 2.93$ & $187.6 \pm 2.62$ & $182.9 \pm 5.01$ & $173.3 \pm 5.19 *$ \\
GPT $(\mathrm{UI} / \mathrm{L})$ & $63.04 \pm 0.4$ & $55.87 \pm 2.65$ & $52.25 \pm 17.6$ & $49.11 \pm 18.61$ \\
ALP $(\mathrm{UI} / \mathrm{L})$ & $264.6 \pm 1.98$ & $209.7 \pm 10.05 *$ & $202.7 \pm 19.79 *$ & $180.4 \pm 11.50 *$ \\
CPK $(\mathrm{UI} / \mathrm{L})$ & $101.4 \pm 0.87$ & $91.86 \pm 3.59$ & $90.12 \pm 4.11$ & $89.38 \pm 9.38$ \\
LDH $(\mathrm{UI} / \mathrm{L})$ & $242.5 \pm 2.92$ & $243.5 \pm 6.24$ & $220 \pm 14.01$ & $195.4 \pm 5.32 *$ \\
\hline
\end{tabular}

$*$ : significantly different from the control.

WBC : White blood cells; RBC : Red blood cells; Hb : Hemoglobin; HCT : Hematocrit; MCHC : Mean corpuscular hemoglobin concentration; GOT : Glutamo-oxaloacetic Transaminase ; GPT : Glutamo-Pyruvic Transaminase; ALP : Alkaline Phosphatase; CPK : Creatine Phosphokinase; LDH : Lactate dehydrogenase.

\section{DISCUSSION}

The results of acute toxicity tests showed that increasing the dose of the total extract of MYTA led to an increase in mortality in mice subjected to the test, and the proportion of affected animals increased with increasing dose. This suggests that there is then a dose-response relationship between the dose of the extract administered and mortality recorded in animals (Fatima et al., 2010).

This study determined the acute toxicity parameters of total methanolic extract after intra-peritoneal injection in mice. These are: the MTD $\left(500 \mathrm{mg} / \mathrm{kg}\right.$ of bw), the $\mathrm{LD}_{50}$ (1412 mg/kg of bw) and $\mathrm{LD}_{100}(4000 \mathrm{mg} / \mathrm{kg}$ bw). These parameters indicate that the administration of doses below the MTD induced no mortality, as also shown by Lapointe (2004) and Fatima et al. (2010).

However, doses above the MTD induces deaths for which the rate varies with the dose (Kouassi, 2006). At doses between MTD and the $\mathrm{LD}_{50}$, the mortality rate of female mice is higher than that of males (Laroche et al., 1986). At doses above the $\mathrm{LD}_{50}$, the mortality rate among males is higher (Laroche et al., 1986; Sitwell, 2007). Generally, the $\mathrm{LD}_{50}$ reflects the lethal nature of a substance (Langley et al., 2003).

Moreover, the time of action of the product was faster in female mice than in males. This suggests that female mice are more sensitive to the total methanolic extract of Mitragyna ciliata than males. The sensitivity of the animal towards a given drug may vary according to sex (Laroche et al., 1986; Sitwell, 2007).

In addition, the value of $\mathrm{LD}_{50}$ estimated at $1412 \mathrm{mg} / \mathrm{kg}$ bw ( 3 times that of the MTD) in male and female mice helps to classify the total methanolic extract of MYTA as a moderately toxic substance according to the scale of $\mathrm{LD}_{50}$ classification by Cotonat (1996). The clinical signs of toxicity presented by the mice were:

- Respiratory rate acceleration

- Tremor

- Immobilization of the animal.

According to the table of relationship between clinical signs of intoxication and organs (Laroche et al., 1986) or systems (Hachette, 1989), one might infer that the total methanolic extract of MYTA had an effect on the respiratory system. This finding is in agreement with the work performed by Bidie (2005) on the effect of MYTA on rabbit breathing. According to the author, MYTA induced excessive degradation of lungs. It would also have an action on the neuromuscular system.

The results obtained during the 14 days following the 24 hours of observation showed that the total methanolic extract of MYTA, given as a single dose, had a toxic action that extended over a period of $15 \min$ to 3 days. Beyond 24 hours, mice that survived gradually recovered after 5 days. Given this observation, we can say that the product accumulates in the body and its elimination is retarded, resulting in a longer recovery time. 
These results are consistent with the work of Bidie et al. (2010) on the duration of action of MYTA and restoration of carotid blood pressure of rabbits. This suggests that biotransformation of MYTA was slowed, resulting in the accumulation or difficult elimination of metabolites. This could be the basis of damage to organs and tissues.

The study of the subacute toxicity at doses $250 \mathrm{mg} / \mathrm{kg}$ bw and $475 \mathrm{mg} / \mathrm{kg}$ bw in rats led to the following clinical signs: weakening, immobilization, loss of appetite, increased respiratory rate of rats. These signs of intoxication lasted for 2 to 3 days. This may be due to the accumulation of the MYTA in the body. The return to normal of rats treated after 3 days, compared to controls, is evidence that animals have eliminated the product that had been administered. However, the deaths could be explained by the fact that these animals could not eliminate the product accumulated in the body on time. This suggests that the metabolism of MYTA may be difficult.

Furthermore, the results obtained with the serum enzymes (GOT, GPT, ALP, CPK and $\mathrm{LDH}$ ) showed that no significant increase of activity occurred. This indicated that the heart and liver might not have suffered damages. Besides, significant decreases were observed in the serum activities of GOT, ALP and LDH, suggesting that MYTA could have a potential hepatoprotective effect. Nevertheless, significant increases were observed in the serum concentration of urea, uric acid and creatinine. This indicates the accumulation of these metabolites in the blood. This suggests a kidney injury, leading to a decrease in renal elimination of waste. The increase observed may also be due to an increased production of these metabolites.

\section{Conclusion}

These studies of acute and subacute toxicity of the total methanolic extract of MYTA lead to the determination of the MTD $(500 \mathrm{mg} / \mathrm{kg}$ of $\mathrm{bw})$, the $\mathrm{LD}_{50}(1412 \mathrm{mg} / \mathrm{kg}$ of bw) and $\mathrm{LD}_{100}(4000 \mathrm{mg} / \mathrm{kg} \mathrm{bw})$, in addition to some biochemical indices of toxicity. The results obtained showed the moderate toxic nature of the product, suggesting its safe use at therapeutic dose in humans. The observed toxicity is likely due to difficulties in the elimination of MYTA from the body or its metabolism. However, other tests such as histology of organs and chronic toxicity tests among others are necessary to ensure MYTA moderate toxicity.

\section{REFERENCES}

Adjanohoun EJ, Aké Assi L. 1979. Contribution au Recensement des Plantes Médicinales en Côte d'Ivoire. Centre National de Floristique: Abidjan; 358 p.

Aké Assi L, Guinko S. 1991. Plants Used in Traditional Medicine in West Africa. Editiones Roche: Basel, Switzerland; $151 \mathrm{p}$.

Adjétey KAT, Djé KM, Manda-Vangah M, Adoubryn DK, Koné PL, Koné M, Guédé-Guina F. 2007. Antimalarial activity of Mitragyna ciliata (Rubiaceae) Aubrev and Pellegr: Peliminary study. South African Journal of botany, 73(2): 226-229.

Bergmeyer HU, Scheibe P, Wahlefeld AW. 1978. Optimization of methods for aspartate aminotransferase and alanine aminotransferase. Clin. Chem., 24: 58-73.

Behrens B, Karber G. 1935. Wie sind Reihenversuche fur biologische Auswertungen am zweckmassigsten anzuorden? Archives of Experimental Pathology and Pharmacology, 177: 379388.

Bidié AP. 2005. Etude comparative de l'effet inotrope de Mitragyna ciliata (MYTA), de la Mansonine (MSN) et de la Digoxine $(\mathrm{DX})$. Thèse de doctorat $3^{\text {ème }}$ cycle. Université de Cocody, 132p.

Bidié AP, Koffi E, N'guessan JD, Djaman AJ, Guédé-Guina F. 2008. Influence of Mitragyna ciliata (MYTA) on the microsomal activity of ATPase $\mathrm{Na}^{+} / \mathrm{K}^{+}$ dependent extract on a rabbit heart. Afr. $J$. Trad. CAM., 5(3): 294-301.

Bidié AP, Yapo FA, Yéo D, N'guessan JD, Djaman AJ, Guédé-Guina F. 2010. Effet 
de Mitragyna ciliata (MYTA) sur le système cardiovasculaire de rat. Phytothérapie, 8: 1-6.

Cotonat. 1996. La Toxicologie, Point des Connaissances Actuelles. Presse Universitaire de France; 5-25.

Desfontis J-C. 2004. Le modèle animal en expérimentation. UPSD 5304 Physiologie Animale et Pharmacologie fonctionnelle. Département de biologie et pharmacie. Ecole Nationale Vétérinaire de Nantes, 4 p.

Djé MK, Djaman AJ, Mazabrau A. GuedéGuina F. 1997. Activité antiplasmodiale des alcaloïdes totaux de Mitragyna ciliata sur le Plasmodium falciparum chloroquino-resistant. ABM., 2: 4-9.

Fabiny DL, Ertingshausen G. 1971. Automated reaction-rate method for determination of serum creatinine with the centrifichem. Clin. Chem., 17: 696700 .

Farrance I. 1987. Plasma glucose methods, a review. Clin. Biochem Rev., 8: 55-68.

Fatima ZBA, Hafida M, Samira B, Nacira BB, Sid AM, Joe KM, Michel N. 2010. Évaluation de la toxicité aiguë de la 2hydroxy-méthyl-1(Nphtaloyltryptophyl) aziridine chez le rat Wistar. Ann. Toxicol. Ana. 1-7.

Fofana S. 2004. Exploration biochimique sur le pouvoir immunogène de trois plantes en Côte d'Ivoire: Alstonia boonei (Apocynaceae), Mitragyna ciliata (Rubiaceae) et Terminalia catappa (Combretaceae). Thèse d'état de doctorat en pharmacie, université de Bamako (Mali), 123p.

Fossati P, PRENCIPE L, Berti G. 1980. Use of 3.5-dichloro-2-hydroxybenzene sulfonic acid/4- amino- phenazone chromogenic system in direct enzymatic assays of uric acid in serum and urine. Clin. Chem., 26: 227-231.

Hachette JC. 1989. Toxicologie d'Urgence: Produits Chimiques et Industriels. Edition Masson: Paris; 189p.

Henry RJ, Chiamori N, Golub OJ, Berkman S. 1960. Revised spectrophotometric methods for determination of glutamicoxalacetic transaminase, glutamicpyruvic transaminase, and lacticacid dehydrogenase. Am. J. Clin. Path., 34: 381-398.

Henry RJ, Cannon DC, Winkelman JW. 1974. Clinical Chemistry: Principle and Technique. Harper and Row: New York; 528-538.

IFCC. 1986. Method for L-Aspartate aminotransferase. J. Clin. Chem. Clin. Biochem., 24: 497-510.

Karmen A, Wróblewski F, LaDue JS. 1955. Transaminase activity in human blood. J. Clin. Invest., 34(1): 126-133.

Kouassi K. 2006. Etude de la toxicité aiguë et subaiguë de THOS chez la souris. DEA de Biotechnologie et Amélioration des productions végétales option Pharmacologie des Substances Naturelles. UFR Biosciences, Université de Cocody, Abidjan-Côte d'Ivoire, 30p.

Labbé D, Vassault A, Cherruau B, Baltassat P, Bonète R, Carroger $\mathrm{G}$, Costantini $\mathrm{A}$, Guérin S, Houot O, Lacour B, Nicolas A, Thioulouse E, Trépo D. 1996. Method selected for the determination of creatinine in plasma or serum. Choice of optimal conditions of measurement (in French), Ann. Biol. Clin., 54: 285-298.

Langley C, Langley G. 2003. Les tests sur les animaux dans l'industrie des cosmétiques en France. Chap IV: les tests des produits cosmétiques sur les animaux : une critique scientifique, $2 \mathrm{p}$

Lapointe G. 2004. Notion de toxicologie. 2 éd rev et augm.- (Montréal). Commission de la Santé et de la Sécurité du Travail (CSST) Québec, Direction de la prévention-inspection, service du répertoire Toxicologique: Direction des communications, 8-16p.

Laroche MJ, Fabiani P, Rousselet F. 1986. L'Expertise Toxicologique des Médicaments. Edition Masson: Paris; $367 \mathrm{p}$. 
Sitwell J, Savard LS, Bose R. 2007. Détermination du terme «toxique» pour les besoins des dispositifs relatifs aux substances nouvelles (produit chimiques et polymères) de la loi canadienne sur la protection de l'environnement-considérations relatives à la santé humaine. Santé de l'environnement et du milieu de travail, Santé Canada, $\mathrm{N}^{\circ}$ cat H 128-1/06-477, $5 \mathrm{p}$.

Talke H, Schubert GE. 1965. Enzymatische Harnstoff bestimmung in Blut and serum in Optischen Test nach Warburg, Klin Wochschr 43 p. 174.

Tietz NW. 1999. Text Book of Clinical Chemistry (3rd edn). C.A. Burtis, E.R. Ashwood, W.B. Saunders; 1245-1250.

Tiffany TO, Jansen JM, Burtis C A, Overton JB, Scott CD. 1972. Enzymatic kinetic rate and end-point analyses of substrate by use of a Gemsaec Fast Analyzer. Clin. Chem., 18: 829-840.
Trinder P. 1969. Determination of glucose in blood using glucose oxydase with an alternative oxygen receptor. Ann Clin Biochem., 6: 24-27.

Withold W, Schulte U, Reinauer H, 1996. Method for determination of bone alkaline phosphatase activity: analytical performance and clinica usefulness in patients with metabolic and malignant bone diseases. Clin. Chem., 42(2): 210217.

Yapi HF, Ahiboh H, Edjeme A, HauhouotAttoungbé M.L, Djaman AJ, Monnet D. 2009. Déficit en fer, profil immunitaire, inflammatoire et nutritionnel chez l'enfant de Côte d'Ivoire. Cahiers Santé, 19(1. 52): 2528. 